\title{
DUKUNGAN SOSIAL BAGI WARGA PENDERITA GANGGUAN JIWA DI JOGONALAN KIDUL, TIRTONIRMOLO, KASIHAN, BANTUL
}

\author{
Arsitha Kumalasari, Amika Wardana, Ph.D., dan Aris Martiana, M.Si. \\ Program Studi Pendidikan Sosiologi, Fakultas IImu Sosial, Universitas Negeri Yogyakarta \\ arsitha.kumalasari2015@student.uny.ac.id
}

\begin{abstract}
Abstrak
Penelitian ini bertujuan untuk mengetahui bentuk dukungan sosial bagi warga penderita gangguan jiwa di Jogonalan Kidul, Tirtonirmolo, Kasihan, Bantul. Penelitian ini menggunakan metode kualitatif deskriptif. Teknik pengumpulan data dengan observasi, wawancara, dan dokumentasi. Informan di dalam penelitian ini adalah keluarga dari penderita gangguan jiwa, tetangga sekitar tempat tinggal penderita gangguan jiwa, dan pemerintah setempat. Informan dipilih menggunakan teknik purposive sampling. Keabsahan data diperiksa dengan menggunakan teknik triangulasi sumber. Teknik analisis data menggunakan model interaktif Miles dan Huberman yang meliputi tahap pengumpulan data, reduksi data, penyajian data, dan penarikan kesimpulan. Hasil penelitian ini menunjukkan bahwa dukungan sosial bagi warga penderita gangguan jiwa di Jogonalan Kidul, Tirtonirmolo, Kasihan, Bantul diberikan oleh pihak keluarga, masyarakat, maupun pemerintah setempat. Dukungan sosial paling banyak diberikan oleh keluarga adalah dukungan instrumental. Dukungan sosial yang diberikan oleh masyarakat paling banyak adalah dukungan kelompok. Sedangkan dukungan sosial dari pemerintah setempat paling banyak adalah dukungan informasi.
\end{abstract}

Kata Kunci: Dukungan, Dukungan Sosial, Gangguan Jiwa

\section{Abstract}

The purpose of this research for knowing kind social support for mental disorders people in Jogonalan Kidul, Tirtonirmolo, Kasihan, Bantul. This research used descriptive qualitative method. Data collection techniques with observation, interview, and documentation. The informan in this reseacrh are disorders mental's family, neighbor, and local government. Informants in this study selected by using purposive sampling technique. The validity of the data was checked using the technique of triangulation of sources. Data analysis techniques used in this study were Miles and Huberman's data analysis techniques include data collection, data reduction, data presentation, and conclusion drawing. The results of this research show that social support for mental disorders people in Jogonalan Kidul, Tirtonirmolo, Kasihan, Bantul was given by family, public, and local government. Social support at the most given by family is instrumental support. Social support at the most given by public is group support. And then social support at the most given by local government is information support.

Keywords: Support, Social Support, Mental Disorders

\section{Pendahuluan}

Gangguan jiwa menjadi topik yang cukup banyak dibicarakan diantara kalangan ahli medis dan sosial, karena menimbang angka kasus yang cukup banyak terjadi di dunia. Berdasarkan data dari World Health Organization (WHO) (Yosep, 2013), terdapat sekitar 450 juta orang di dunia yang mengalami gangguan jiwa. World Health Organization (WHO) menyatakan setidaknya ada satu dari empat orang di dunia mengalami masalah kejiwaan. 
Di Indonesia kasus penderita gangguan jiwa juga cukup banyak. Salah satunya ditunjukkan dengan data status kesehatan jiwa di Indonesia yang dilihat dari hasil riset Badan Penelitian Pengembangan Kesehatan oleh Departemen Kesehatan yang menunjukkan prevalensi gangguan jiwa berat di Indonesia sebesar 4,6 permil. Dengan kata lain 1000 penduduk Indonesia empat sampai lima diantaranya mengalami gangguan jiwa dan dapat menyerang siapa saja dengan tidak memandang ras, kebudayaan, kelas sosial, maupun jenis kelamin (Wardani, 2009).

Berdasarkan hasil Riset Kesehatan Dasar (Riskesdas) tahun 2013 oleh Kementerian Kesehatan Republik Indonesia, wilayah Daerah Istimewa Yogyakarta menempati posisi tertinggi kasus anggota keluarga yang memiliki orang dengan gangguan jiwa skizofrenia atau gangguan jiwa berat (Departemen Kesehatan RI, 2013). Sedangkan menurut hasil Riset Kesehatan Dasar tahun 2018, wilayah Daerah Istimewa Yogyakarta turun satu tingkat menjadi nomor dua. Akan tetapi, Indonesia mengalami peningkatan proporsi gangguan jiwa yang cukup signifikan jika dibandingkan dengan hasil Riset Kesehatan Dasar tahun 2013, yakni naik dari 1,7 persen menjadi 7 persen (Departemen Kesehatan RI, 2018). Menurut Townsend (dalam Wardani, 2009) menyatakan bahwa gangguan jiwa merupakan respon maladaptif terhadap stresor dari lingkungan internal dan eksternal yang ditunjukkan dengan pikiran, perasaan, dan tingkah laku yang tidak sesuai dengan norma lokal dan budaya setempat, serta mengganggu fungsi sosial, pekerjaan, dan fisik individu.

Sesuai dengan Undang-Undang Nomor 18 tahun 2014 tentang Kesehatan Jiwa yang ditujukan untuk menjamin setiap orang agar dapat mencapai kualitas hidup yang baik serta memberikan pelayanan kesehatan secara terintegrasi, komprehensif, dan berkesinambungan melalui upaya promotif, preventif, kuratif, dan rehabilitatif. Secara garis besar undangundang tersebut berisi tentang salah satunya yaitu perlunya peran serta masyarakat dalam melindungi dan memberdayakan ODGJ (Orang Dengan Gangguan Jiwa) dalam bentuk bantuan yang dapat berupa tenaga, dana, fasilitas, pengobatan bagi Orang Dengan Gangguan Jiwa (ODGJ), dan perlindungan terhadap tindakan kekerasan, menciptakan lingkungan yang kondusif, serta memberikan pelatihan keterampilan.

Dukungan sosial pada umumnya diartikan sebagai keberadaan orang lain yang dapat dipercaya, orang yang dapat membuat seseorang merasa dipedulikan, berharga, dan dicintai. Inti dari dukungan sosial adalah mengetahui bahwa orang lain mencintai dan mau melakukan 
sesuatu yang dapat mereka lakukan untuk kita. Dukungan sosial dapat berbentuk seperti mendorong, menolong, bekerjasama, menunjukkan persetujuan, cinta, dan afeksi fisik. Dukungan sosial juga membantu memperkuat fungsi kekebalan tubuh, mengurangi respons fisiologis terhadap stress, dan memperkuat fungsi untuk merespons penyakit kronis (Taylor, 2009). Dukungan sosial (social support) didefinisikan oleh Kuntjoro (2002), sebagai informasi verbal atau nonverbal, saran, bantuan yang nyata, atau tingkah laku yang diberikan oleh orang-orang yang akrab dengan partisipan di lingkungan sosialnya atau yang berupa kehadiran dan hal-hal yang dapat memberikan keuntungan emosional atau berpengaruh pada tingkah laku penerimanya. Dalam hal ini, orang yang merasa memperoleh dukungan sosial, secara emosional merasa lega karena diperhatikan, karena mendapat saran atau kesan yang menyenangkan pada dirinya.

Berdasarkan data dari Puskesmas Kasihan II, terdapat 60 penderita ODGJ, sedangkan untuk pedukuhan Jogonalan Kidul sendiri terdapat 29 ODGJ yang terdiri dari berbagai macam jenis gangguan jiwa (Data Puskesmas Kasihan II, 2018). Di pedukuhan Jogonalan Kidul, masyarakat dan penderita gangguan jiwa hidup berdampingan selayaknya masyarakat dengan kondisi normal lainnya. Padahal di daerah tersebut cukup banyak penderita gangguan jiwa.
Akan tetapi pihak keluarga tetap membiarkan mereka tinggal di rumah, bahkan tidak ada usaha untuk mengurungnya di dalam rumah. Di setiap pedukuhan juga terdapat kader-kader kesehatan yang bekerjasama dengan puskesmas yang khusus menangani penderita gangguan jiwa.

\section{Metode}

Bentuk penelitian ini merupakan penelitian kualitatif dengan pendekatan deskriptif. Hasil penelitian ini berupa kutipan-kutipan data untuk memberikan deskripsi penyajian laporan tersebut. Data yang diperoleh dapat berasal dari observasi, wawancara, foto dokumentasi dari kader jiwa, dan dokumen daftar penderita gangguan jiwa dari Puskesmas Kasihan II.

Penelitian dilakukan di pedukuhan Jogonalan Kidul, desa Tirtonirmolo yang terletak di kecamatan Kasihan kabupaten Bantul. Peneliti memilih lokasi ini dikarenakan wilayah pedukuhan Jogonalan Kidul banyak ditemui penderita gangguan jiwa yang menjalani perawatan di rumah.

Penelitian terkait dukungan sosial bagi warga penderita gangguan jiwa di Jogonalan Kidul, Tirtonirmolo, Kasihan, Bantul dilaksanakan selama kurang lebih 3 (tiga) bulan.

Subyek penelitian dibutuhkan dalam mencari informasi dan data mengenai fokus penelitian. Data yang diperoleh tersebut digunakan untuk 
menambah data terkait dukungan sosial bagi warga penderita gangguan jiwa khususnya di wilayah Jogonalan Kidul, Tirtonirmolo, Kasihan, Bantul. Kriteria dalam subyek penelitian ini adalah keluarga dari penderita gangguan jiwa yang meliputi informan berinisial ND, NI, dan S, lalu masyarakat yang meliputi tetangga penderita gangguan jiwa dengan informan berinisial DR, AW, dan $\mathrm{SL}$, selanjutnya pemerintah setempat yang berkaitan dengan penderita gangguan jiwa yang meliputi Ketua PKK Jogonalan Kidul berinisial SUM, perawat bagian psikologi puskesmas yang berinisial SM, dan juga koordinator kader jiwa Jogonalan Kidul yang berinisial AK.

Sumber data yang digunakan peneliti terbagi menjadi dua, yaitu sumber data primer dan sumber data sekunder. Sumber data primer dalam penelitian ini adalah keluarga penderita gangguan jiwa berdasarkan hasil wawancara peneliti mendapatkan informasi dari 3 orang tua penderita gangguan jiwa, masyarakat yang meliputi tetangga penderita gangguan jiwa, serta pemerintah setempat yang berkaitan langsung dengan warga penderita gangguan jiwa di Jogonalan Kidul yang meliputi ketua PKK Jogonalan Kidul, perawat psikologi Puskesmas Kasihan II, dan koordinator kader jiwa Jogonalan Kidul.

Sumber data sekunder diperoleh dari data kependudukan dan wilayah desa, data jumlah penderita gangguan jiwa dari Puskesmas Kasihan II, foto kegiatan kader jiwa, daftar anggota kader jiwa di Jogonalan Kidul untuk mendukung hasil penelitian. buku-buku referensi, jurnal, penelitian yang sudah dilakukan sebelumnya, serta situs internet yang berkaitan dengan penelitian yang dilakukan.

Teknik pengumpulan data yang digunakan adalah observasi, wawancara, dan dokumentasi. Peneliti mengamati lokasi penelitian yang meliputi lokasi tempat tinggal penderita, kondisi geografis, jangkauan layanan kesehatan, kondisi sosial penduduk, aktivitas masyarakat dan penderita gangguan jiwa serta interaksi keluarga, masyarakat, dan pemerintah setempat dengan warga penderita gangguan jiwa. Wawancara dilakukan kepada informan yang mengetahui terkait warga penderita gangguan jiwa di pedukuhan Jogonalan Kidul. Wawancara yang dilakukan pada penelitian ini adalah wawancara terstruktur dan juga terarah. Maka dari itu dalam penelitian ini dibuat instrumen wawancara dalam bentuk pertanyaan tertulis. Teknik ini digunakan untuk menjaring data-data primer yang berkaitan dengan fokus penelitian sehingga tidak terlalu melebar dari pembahasan yang akan diteliti. Dalam penelitian ini, peneliti melakukan wawancara dengan keluarga penderita, masyarakat atau tetangga sekitar tempat tinggal, dan pihak dari pemerintah setempat yang terkait dengan warga penderita gangguan jiwa. Selain 
menggunakan observasi dan wawancara, dalam penelitian ini juga menggunakan dokumentasi. Dokumentasi adalah suatu teknik pengumpulan data yang ditujukan kepada subyek penelitian. Dokumentasi pada penelitian lebih kepada pendukung data-data penelitian yang dibutuhkan. Dalam penelitian ini, peneliti menggunakan data jumlah penderita gangguan jiwa dari dokumen Puskesmas Kasihan II, foto kegiatan kader jiwa, daftar anggota kader jiwa di Jogonalan Kidul, dan data monografi desa untuk mendukung hasil penelitian.

Dalam penelitian ini peneliti menggunakan teknik pengambilan sampel purposive sampling yaitu teknik yang bertujuan untuk menjaring sebanyak mungkin informasi dari berbagai macam sumber (Moleong, 2011). Dalam teknik tersebut dibuat kriteria atau pertimbangan tertentu, dalam hal ini kriteria yang diambil yaitu :

1. Keluarga yang merupakan keluarga terdekat, tinggal dalam satu rumah dengan penderita, atau yang sering merawat penderita gangguan jiwa untuk lebih khususnya diutamakan orangtua penderita gangguan jiwa. Dalam penelitian ini, peneliti mendapatkan sebanyak 3 informan yaitu informan ND yang merupakan ibu kandung penderita, informan S yang merupakan ibu kandung penderita, dan informan $\mathrm{NI}$ yang merupakan ayah kandung penderita.
2. Masyarakat yang merupakan tetangga dari warga penderita gangguan jiwa dengan jarak 1 sampai 3 rumah dari tempat penderita gangguan jiwa tinggal. Dalam penelitian ini, peneliti mendapakan sebanyak 3 informan yang merupakan tetangga dari penderita gangguan jiwa yaitu informan SL yang berjarak 3 rumah dengan penderita, informan DR yang berjarak 2 rumah dengan penderita, dan informan AW yang berjarak 2 rumah dengan penderita.

3. Pemerintah yang merupakan pemerintah setempat yang meliputi perangkat dukuh, puskesmas setempat, atau kader-kader kesehatan yang berkaitan dengan warga penderita gangguan jiwa. Dalam penelitian ini, peneliti mendapat sebanyak 3 informan meliputi informan SUM yang merupakan ketua PKK pedukuhan Jogonalan Kidul atau ibu dukuh, informan SM yang merupakan perawat psikolog puskesmas yang membantu pengobatan serta menangangi permasalahan gangguan jiwa di Jogonalan Kidul, serta informan AK yang merupakan koordinator kader jiwa pedukuhan Jogonalan Kidul.

Pemeriksaan atau validasi data dalam penelitian ini menggunakan triangulasi sumber. Triangulasi sumber untuk mengkaji kredibilitas data dilakukan 
dengan cara mengecek data yang telah diperoleh melalui beberapa sumber, yaitu melalui observasi, wawancara, dan dokumentasi. Peneliti akan membandingkan hasil wawancara pada setiap informan satu dengan informan yang lain yang telah sesuai dengan kriteria peneliti dan melakukan konfirmasi dengan wawancara salah satu penderita gangguan jiwa.

Penelitian ini menggunakan analisis data seperti yang dikemukakan oleh Miles dan Huberman (dalam Sugiyono, 2016:246) yang mengemukakan bahwa aktivitas dalam analisis data kualitatif dilakukan secara interaktif dan berlangsung secara terus menerus sehingga mencapai data jenuh. Model interaktif yang dikembangkan oleh Miles dan Huberman yang terdiri dari reduksi data, pengumpulan data, penyajian data, dan penarikan kesimpulan atau verifikasi.

\section{Hasil dan Pembahasan}

\section{Dukungan Sosial dari Keluarga bagi Warga Penderita Gangguan Jiwa}

Dukungan sosial dari keluarga merupakan dukungan yang paling penting dalam membantu penderita gangguan jiwa agar segera pulih dan dapat menjalankan perannya di masyarakat. Teori yang dikemukakan oleh Rock \& Dooley dalam penelitiannya tentang dukungan keluarga bagi penderita gangguan jiwa menyatakan bahwa keluarga memainkan suatu peranan bersifat mendukung selama penyembuhan dan pemulihan anggota keluarga sehingga mereka dapat mencapai tingkat kesejahteraan optimal (Kuntjoro, 2002). Berikut merupakan dukungan sosial dari keluarga bagi warga penderita gangguan jiwa di Jogonalan Kidul, Tirtonirmolo, Kasihan, Bantul yang disajikan dalam tabel:

\begin{tabular}{|c|c|c|}
\hline No & $\begin{array}{c}\text { Bentuk } \\
\text { Dukungan } \\
\text { Sosial }\end{array}$ & $\begin{array}{c}\text { Contoh Dukungan } \\
\text { Sosial }\end{array}$ \\
\hline 1 & $\begin{array}{l}\text { Dukungan } \\
\text { Emosional- } \\
\text { Afektif }\end{array}$ & $\begin{array}{l}\text { Karena penderita } \\
\text { merupakan } \\
\text { anggota } \\
\text { keluarganya } \\
\text { sendiri sehingga } \\
\text { anggota keluarga } \\
\text { lain terutama } \\
\text { orangtua } \\
\text { penderita merasa } \\
\text { bertanggungjawa } \\
\text { b atas anggota } \\
\text { keluarganya. } \\
\text { Penerimaan } \\
\text { anggota keluarga } \\
\text { yang lain } \\
\text { terhadap } \\
\text { anggota } \\
\text { keluarganya } \\
\text { yang menderita } \\
\text { gangguan jiwa. } \\
\text { Hal ini akan } \\
\text { membuat } \\
\text { keluarga } \\
\text { bersikap terbuka } \\
\text { terhadap orang } \\
\text { lain bahwa } \\
\text { keluarganya } \\
\text { memiliki anggota } \\
\text { keluarga yang } \\
\text { menderita } \\
\text { gangguan jiwa. } \\
\text { Anggota } \\
\text { keluarga } \\
\text { menunjukkan } \\
\text { rasa perhatian } \\
\text { dan kepedulian } \\
\text { dengan } \\
\text { membawa } \\
\text { penderita Katika } \\
\text { berobat. Kanderita } \\
\text { pendenan } \\
\text { menunukkan } \\
\text { suatu perubahan } \\
\text { perilaku maka }\end{array}$ \\
\hline
\end{tabular}




\begin{tabular}{|c|c|c|}
\hline No & $\begin{array}{c}\text { Bentuk } \\
\text { Dukungan } \\
\text { Sosial }\end{array}$ & $\begin{array}{c}\text { Contoh Dukungan } \\
\text { Sosial }\end{array}$ \\
\hline & & $\begin{array}{l}\text { anggota keluarga } \\
\text { dengan segera } \\
\text { mencarikan } \\
\text { pengobatan. } \\
\text { Perhatian dalam } \\
\text { merawat } \\
\text { penderita } \\
\text { gangguan jiwa } \\
\text { juga ditunjukkan } \\
\text { dengan selalu } \\
\text { mengawasi } \\
\text { penderita dalam } \\
\text { mengkonsumsi } \\
\text { obat. }\end{array}$ \\
\hline 2 & $\begin{array}{l}\text { Dukungan } \\
\text { Pengharga } \\
\text { an }\end{array}$ & $\begin{array}{l}\text { Karena penderita } \\
\text { gangguan jiwa } \\
\text { harus terus } \\
\text { mengkonsumsi } \\
\text { obat dan tidak } \\
\text { boleh } \\
\text { terlewatkan } \\
\text { sehingga } \\
\text { keluarga selalu } \\
\text { memberikan } \\
\text { semangat } \\
\text { kepada anggota } \\
\text { keluarganya } \\
\text { yang menderita } \\
\text { gangguan jiwa } \\
\text { jika mau rutin } \\
\text { meminum obat. } \\
\text { Karena } \\
\text { terkadang } \\
\text { penderita muncul } \\
\text { rasa bosan dan } \\
\text { tidak mau minum } \\
\text { obat. a } \\
\text { Anggota } \\
\text { keluarga akan } \\
\text { memberikan } \\
\text { pujian ketika } \\
\text { penderita } \\
\text { menunjukkan } \\
\text { perkembangan } \\
\text { seperti dapat } \\
\text { melakukan } \\
\text { pekerjaan rumah } \\
\text { seperti menyapu } \\
\text { dan menjemur } \\
\text { pakaian. }\end{array}$ \\
\hline 3 & $\begin{array}{l}\text { Dukungan } \\
\text { Instrument } \\
\text { al }\end{array}$ & $\begin{array}{l}\text { Karena penderita } \\
\text { tidak produktif } \\
\text { dab tidak bekerja } \\
\text { sehingga } \\
\text { keluarga } \\
\text { membiayai } \\
\text { kebutuhan } \\
\text { sehari-hari }\end{array}$ \\
\hline
\end{tabular}

\begin{tabular}{|c|c|c|}
\hline No & $\begin{array}{l}\text { Bentuk } \\
\text { Dukungan }\end{array}$ & $\begin{array}{c}\text { Contoh Dukungan } \\
\text { Sosial }\end{array}$ \\
\hline & & $\begin{array}{l}\text { penderita seperti } \\
\text { kebutuhan } \\
\text { sandang dan } \\
\text { pangan. } \\
\text { Keluarga } \\
\text { membiayai } \\
\text { pengobatan } \\
\text { penderita dari } \\
\text { awal hingga } \\
\text { penderita dapat } \\
\text { pulih kembali. } \\
\text { Beberapa } \\
\text { penderita belum } \\
\text { mendapatkan } \\
\text { jaminan } \\
\text { kesehatan } \\
\text { sehingga } \\
\text { keluarga harus } \\
\text { mengeluarkan } \\
\text { uang lebih untuk } \\
\text { dapat membiayai } \\
\text { pengobatan } \\
\text { penderita. }\end{array}$ \\
\hline 4 & $\begin{array}{l}\text { Dukungan } \\
\text { Informasi }\end{array}$ & \begin{tabular}{lr} 
- & \multicolumn{2}{l}{ Keluarga juga } \\
memberikan \\
perhatian dengan \\
selalu memberi \\
nasehat agar \\
tidak banyak \\
pikiran dan \\
menjaga emosi. \\
- Informasi dan \\
anjuran dari \\
dokter berkaitan \\
dengan \\
pengobatan \\
penderita \\
diberikan kepada \\
anggota \\
keluarga. Tugas \\
keluarga \\
menyampaikan \\
anjuran-anjuran \\
dari dokter \\
kepada \\
penderita.
\end{tabular} \\
\hline 5 & $\begin{array}{l}\text { Dukungan } \\
\text { Kelompok }\end{array}$ & 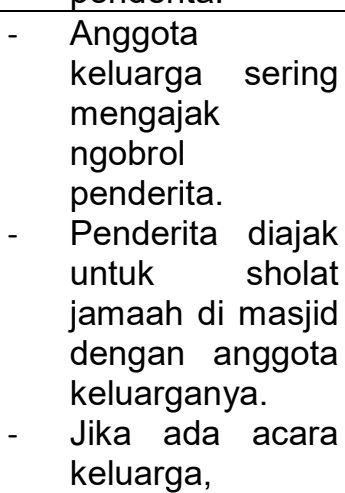 \\
\hline
\end{tabular}




\begin{tabular}{|c|c|c|}
\hline No & $\begin{array}{c}\text { Bentuk } \\
\text { Dukungan } \\
\text { Sosial }\end{array}$ & $\begin{array}{c}\text { Contoh Dukungan } \\
\text { Sosial }\end{array}$ \\
\hline & & $\begin{array}{l}\text { penderita juga } \\
\text { diajak untuk ikut } \\
\text { serta. Akan tetapi } \\
\text { beberapa } \\
\text { penderita yang } \\
\text { kondisinya masih } \\
\text { kurang stabil } \\
\text { hanya diajak ke } \\
\text { acara keluarga } \\
\text { jika lokasinya } \\
\text { dekat dengan } \\
\text { tempat tinggal } \\
\text { penderita. }\end{array}$ \\
\hline
\end{tabular}

\section{Dukungan Sosial dari Masyarakat} bagi Warga Penderita Gangguan Jiwa

Di masyarakat Indonesia masih terdapat stigma tentang penderita gangguan jiwa yang mengganggu kenyamaan. Padahal dukungan dari masyarakat sekitar tempat tinggal penderita gangguan jiwa juga sangat penting. Penerimaan masyarakat terhadap penderita gangguan jiwa dapat mempermudah penderita untuk dapat bersosialisasi dengan masyarakat. Dukungan sosial yang diberikan masyarakat kepada penderita gangguan jiwa bersumber dari adanya interaksi sosial. Interaksi sosial tersebut terjadi dengan penderita maupun dengan keluarga penderita. Interaksi sosial yang terjadi merupakan interaksi non-formal seperti hanya berawal dari menyapa, mengajak berbicara, atau melakukan sesuatu. Berikut merupakan dukungan sosial dari masyarakat bagi warga penderita gangguan jiwa di Jogonalan Kidul, Tirtonirmolo, Kasihan, Bantul:

\begin{tabular}{|c|c|c|}
\hline No & $\begin{array}{c}\text { Bentuk } \\
\text { Dukungan } \\
\text { Sosial }\end{array}$ & $\begin{array}{c}\text { Contoh Dukungan } \\
\text { Sosial }\end{array}$ \\
\hline 1 & $\begin{array}{l}\text { Dukungan } \\
\text { Emosional }\end{array}$ & $\begin{array}{l}\text { Masyarakat } \\
\text { merasa prihatin } \\
\text { karena } \\
\text { tetangganya ada } \\
\text { yang menderita } \\
\text { gangguan jiwa. } \\
\text { Mereka juga } \\
\text { merasa kasihan } \\
\text { akan kondisi } \\
\text { penderita, } \\
\text { sehingga } \\
\text { menyarankan } \\
\text { keluarga untuk } \\
\text { segera } \\
\text { membawa } \\
\text { penderita } \\
\text { berobat. Karena } \\
\text { sikap keluarga } \\
\text { yang terbuka } \\
\text { membuat } \\
\text { tetangga sekitar } \\
\text { juga bersimpati } \\
\text { dengan } \\
\text { penderita. } \\
\text { Tetangga juga } \\
\text { menunjukkan } \\
\text { kepedulian } \\
\text { kepada penderita } \\
\text { dengan } \\
\text { memberikan } \\
\text { pekerjaan ringan } \\
\text { kepada penderita } \\
\text { seperti bersih- } \\
\text { bersih rumah dan } \\
\text { membantu } \\
\text { mencuci } \\
\text { laundry. }\end{array}$ \\
\hline 2 & $\begin{array}{l}\text { Dukungan } \\
\text { Penghargaan }\end{array}$ & 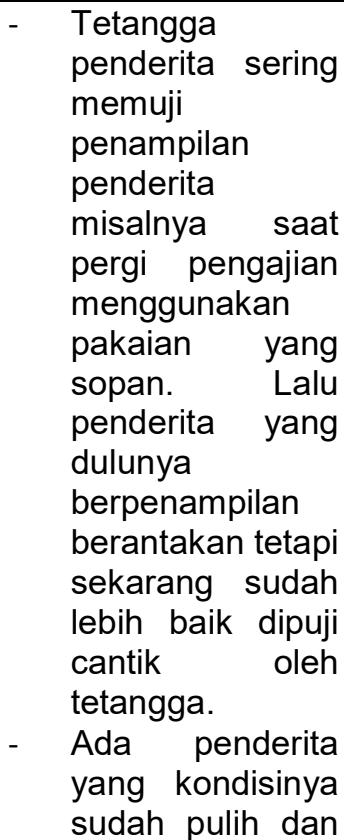 \\
\hline
\end{tabular}




\begin{tabular}{|c|c|c|}
\hline No & $\begin{array}{c}\text { Bentuk } \\
\text { Dukungan } \\
\text { Sosial }\end{array}$ & $\begin{array}{c}\text { Contoh Dukungan } \\
\text { Sosial }\end{array}$ \\
\hline & & $\begin{array}{l}\text { dapat bekerja } \\
\text { kembali, saat } \\
\text { bertemu dengan } \\
\text { penderita } \\
\text { memberikan } \\
\text { ucapan selamat } \\
\text { karena penderita } \\
\text { dapat bekerja } \\
\text { kembali. }\end{array}$ \\
\hline 3 & $\begin{array}{l}\text { Dukungan } \\
\text { Instrumental }\end{array}$ & $\begin{array}{l}\text { Terdapat } \\
\text { informan yang } \\
\text { merupakan } \\
\text { tetangga } \\
\text { penderita } \\
\text { memberikan } \\
\text { pekerjaan ringan } \\
\text { untuk membantu } \\
\text { penderita } \\
\text { memenuhi } \\
\text { kebutuhannya } \\
\text { karena penderita } \\
\text { hidup sendirian. } \\
\text { Jika ada } \\
\text { tetangga yang } \\
\text { hajatan, } \\
\text { penderita juga } \\
\text { mendapatkan } \\
\text { makanan dari } \\
\text { hajatan dan } \\
\text { tahlilan. Terdapat } \\
\text { pula tetangga } \\
\text { yang sewaktu- } \\
\text { waktu saba } \\
\text { memberikan } \\
\text { makanan saat } \\
\text { masakannya } \\
\text { banyak. } \\
\text { Beberapa juga } \\
\text { informan jecara } \\
\text { memberikan } \\
\text { uang sadi secara } \\
\text { pribadi kepada } \\
\text { penderita } \\
\text { gangguan jiwa. }\end{array}$ \\
\hline 4 & $\begin{array}{l}\text { Dukungan } \\
\text { Informasi }\end{array}$ & $\begin{array}{l}\text { Saat mengetahui } \\
\text { tetangganya } \\
\text { berubah } \\
\text { perilakunya, } \\
\text { tetangga } \\
\text { memberikan } \\
\text { saran kepada } \\
\text { keluarga } \\
\text { penderita untuk } \\
\text { membawanya } \\
\text { berobat ke rumah } \\
\text { sakit jiwa atau } \\
\text { puskesmas. }\end{array}$ \\
\hline
\end{tabular}

\begin{tabular}{|c|c|c|}
\hline No & $\begin{array}{c}\text { Bentuk } \\
\text { Dukungan } \\
\text { Sosial }\end{array}$ & $\begin{array}{c}\text { Contoh Dukungan } \\
\text { Sosial }\end{array}$ \\
\hline & & $\begin{array}{l}\text { Saat bertemu } \\
\text { dengan } \\
\text { penderita, } \\
\text { tetangga } \\
\text { penderita juga } \\
\text { mengingatkan } \\
\text { penderita untuk } \\
\text { jangan lupa } \\
\text { minum obat. } \\
\text { Beberapa } \\
\text { tetangga yang } \\
\text { dekat dengan } \\
\text { penderita } \\
\text { memberikan } \\
\text { nasehat } \\
\text { berkaitan dengan } \\
\text { sikap dan } \\
\text { perilaku } \\
\text { penderita yang } \\
\text { suka marah- } \\
\text { marah kepada } \\
\text { tetangga yang } \\
\text { lain untuk tidak } \\
\text { marah-marah } \\
\text { dengan tetangga } \\
\text { yang lain. }\end{array}$ \\
\hline 5 & $\begin{array}{l}\text { Dukungan } \\
\text { Kelompok }\end{array}$ & $\begin{array}{l}\text { Masyarakat } \\
\text { sekitar } \\
\text { memperbolehkan } \\
\text { penderita untuk } \\
\text { sholat jamaah di } \\
\text { masjid. } \\
\text { Saat ada } \\
\text { tetangga yang } \\
\text { rewang, } \\
\text { penderita juga } \\
\text { diperbolehkan } \\
\text { untuk ikut rewang } \\
\text { tetapi melakukan } \\
\text { pekerjaan- } \\
\text { pekerjaan yang } \\
\text { ringan. } \\
\text { Saat kerja bakti } \\
\text { juga penderita } \\
\text { boleh ikut kerja } \\
\text { bakti walaupun } \\
\text { hanya membantu } \\
\text { sedikit dan lebih } \\
\text { banyak } \\
\text { menghabiskan } \\
\text { makanan. } \\
\text { Penderita boleh } \\
\text { mengikuti } \\
\text { pengajian dan } \\
\text { masyarakat yang } \\
\text { lain } \\
\text { menerimanya. }\end{array}$ \\
\hline
\end{tabular}




\section{Dukungan Sosial dari Pemerintah}

\section{Setempat bagi Warga Penderita} Gangguan Jiwa

Dukungan dari pemerintah setempat membuktikan bahwa terdapat kepedulian atau perhatian kepada warga penderita gangguan jiwa di Jogonalan Kidul. Dukungan dari pemerintah setempat juga menjadikan pemerintah menyediakan fasilitas kesehatan untuk kebutuhan penderita gangguan jiwa. Program-program dari puskesmas juga dibuat untuk memfasilitasi penderita gangguan jiwa. Walaupun dalam pelaksanaannya pasti terdapat kendala maupun kekurangannya. Dalam memberikan dukungan sosialnya, pemerintah setempat melakukan interaksi dengan bantuan kader-kader jiwa. Berikut merupakan dukungan sosial dari pemerintah setempat bagi warga penderita gangguan jiwa di Jogonalan Kidul, Tirtonirmolo, Kasihan, Bantul:

\begin{tabular}{|c|c|c|}
\hline No & $\begin{array}{c}\text { Bentuk } \\
\text { Dukungan } \\
\text { Sosial }\end{array}$ & $\begin{array}{c}\text { Contoh Dukungan } \\
\text { Sosial }\end{array}$ \\
\hline 1 & $\begin{array}{l}\text { Dukungan } \\
\text { Emosional }\end{array}$ & 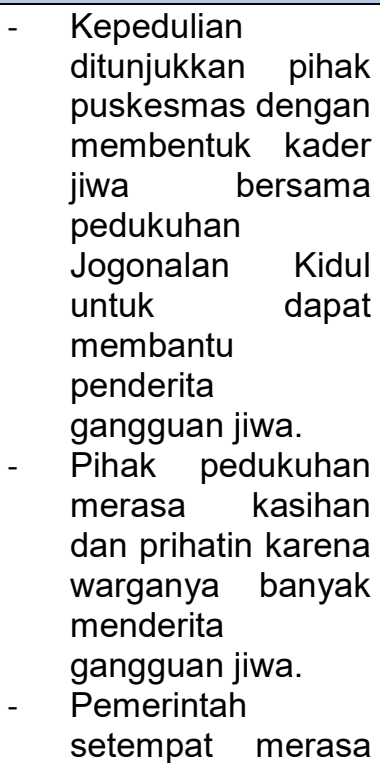 \\
\hline
\end{tabular}

\begin{tabular}{|c|c|c|}
\hline No & $\begin{array}{l}\text { Bentuk } \\
\text { Dukungan } \\
\text { Sosial }\end{array}$ & $\begin{array}{c}\text { Contoh Dukungan } \\
\text { Sosial }\end{array}$ \\
\hline & & $\begin{array}{l}\text { bertanggung jawab } \\
\text { terhadap warganya } \\
\text { yang banyak } \\
\text { mengalami } \\
\text { gangguan jiwa. }\end{array}$ \\
\hline 2 & $\begin{array}{l}\text { Dukungan } \\
\text { Penghargaan }\end{array}$ & 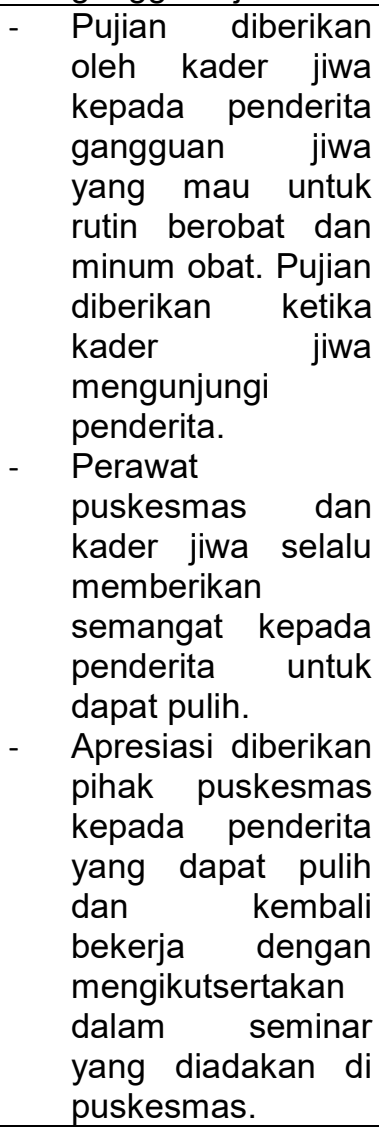 \\
\hline 3 & $\begin{array}{l}\text { Dukungan } \\
\text { Instrumental }\end{array}$ & 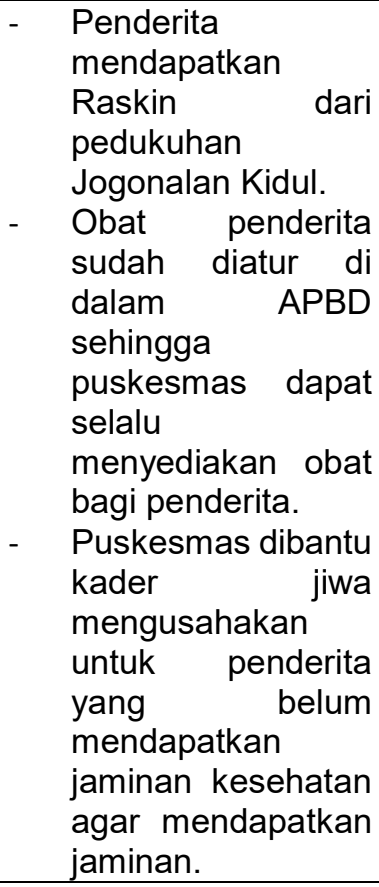 \\
\hline 4 & $\begin{array}{l}\text { Dukungan } \\
\text { Informasi }\end{array}$ & $\begin{array}{l}\text { Informasi } \\
\text { mengenai berbagai } \\
\text { mekanisme }\end{array}$ \\
\hline
\end{tabular}




\begin{tabular}{|c|c|l|}
\hline No & $\begin{array}{c}\text { Bentuk } \\
\text { Dukungan } \\
\text { Sosial }\end{array}$ & $\begin{array}{l}\text { Contoh Dukungan } \\
\text { Sosial }\end{array}$ \\
\hline \multirow{2}{*}{} & & $\begin{array}{l}\text { pengobatan dan } \\
\text { pengetahuan } \\
\text { tentang kesehatan } \\
\text { jiwa diberikan oleh } \\
\text { puskesmas, dan } \\
\text { pedukuhan, dan } \\
\text { kader jiwa kepada } \\
\text { keluarga dan } \\
\text { penderita } \\
\text { gangguan jiwa. }\end{array}$ \\
\hline 5 & Dukungan \\
Kelompok & $\begin{array}{l}\text { Pihak puskesmas } \\
\text { mempunyai } \\
\text { program-program } \\
\text { yang melibatkan } \\
\text { penderita seperti } \\
\text { pelatihan } \\
\text { keterampilan, } \\
\text { family gathering, } \\
\text { dan seminar. }\end{array}$ \\
\hline
\end{tabular}

\section{Simpulan}

Hasil penelitian ini menunjukkan bahwa dukungan sosial bagi warga penderita gangguan jiwa di Jogonalan Kidul, Tirtonirmolo, Kasihan, Bantul diberikan oleh berbagai pihak yaitu dari pihak keluarga, masyarakat, maupun pemerintah setempat. Bentuk dukungan sosial yang diberikan oleh keluarga terdiri dari dukungan emosional, dukungan instrumental, dukungan informasi, dan dukungan kelompok. Akan tetapi dukungan sosial paling besar atau paling banyak diberikan adalah dukungan instrumental karena keluarga tidak hanya membiayai pengobatan penderita akan tetapi juga memenuhi kebutuhan seharihari penderita.

Bentuk dukungan sosial memang diberikan oleh masyarakat, akan tetapi dukungan sosial paling besar dari masyarakat adalah dukungan kelompok. Karena masyarakat Jogonalan Kidul dapat menerima keberadaan penderita gangguan jiwa di wilayahnya. Mereka dapat memaklumi segala perilaku dan tindakan penderita yang tidak seperti orang sehat lainnya. $\mathrm{Di}$ wilayah Jogonalan Kidul juga tidak tercatat adanya penderita yang dikurung maupun dipasung sehingga dapat diakui bahwa tidak ada diskriminasi, hanya pemakluman terhadap penderita gangguan jiwa. Bentuk pemakluman tersebut adalah dengan tidak menuntut penderita melakukan sesuatu yang benar misalnya saat kerja bakti penderita boleh ikut serta tetapi tidak dituntut untuk bekerja atau saat terdapat tetangga yang hajatan penderita boleh ikut rewang atau nyinom tetapi tidak dituntut untuk harus melakukan pekerjaan tersebut.

Bentuk dukungan sosial yang diberikan oleh pemerintah setempat memang terdiri dari dukungan emosional, dukungan instrumental, dukungan informasi, dan dukungan kelompok. Akan tetapi dukungan sosial paling banyak adalah dukungan informasi. Hal ini karena pemerintah selalu membagikan informasi baik kepada penderita maupun keluarga. Informasi tersebut dapat berupa informasi mengenai mekanisme pengobatan, perawatan, maupun kegiatan bagi penderita atau keluarga. Dengan adanya kader jiwa yang diberikan penyuluhan tentang kesehatan jiwa, maka diharapkan dapat menghubungan informasi dari puskesmas kepada pedukuhan lalu 
disampaikan kepada penderita gangguan

jiwa maupun keluarga.

\section{Ucapan Terima Kasih}

Terima kasih kepada semua pihak yang telah mendukung penulisan artikel ini. Kami juga mengucapkan terima kasih kepada redaksi Jurnal Dimensia yang telah menerbitkan tulisan ini.

\section{Daftar Pustaka}

Apollo \& Andi, Cahyadi. 2012. Konflik Peran Ganda Perempuan Menikah yang Bekerja Ditinjau dari Dukungan Sosial Keluarga dan Penyesuaian Diri. Jurnal Psikologi. 02: 261.

Dalami, dkk. 2009. Asuhan Keperawatan Klien dengan Gangguan Jiwa. Yogyakarta: Trans Info Media.

Diningrum Kusuma, S. 2017. Dukungan Sosial Bagi Anak Berhadapan dengan Hukum (ABH) (Studi Terhadap Eks Penerima Manfaat Panti Sosial Marsudi Putra Antasena Magelang). Tersedia di: http://etd.repository.ugm.ac.id. Diakses pada 25 Desember 2018.

Friedman, M. 2010. Buku Ajar Keperawatan Keluarga: Riset, Teori, dan Praktek. Jakarta: EGC

Hartanto, Dwi. 2014. Gambaran Sikap dan Dukungan Keluarga Terhadap Penderita Gangguan Jiwa di Kecamatan Kartasura. Tersedia di: http://eprints.ums.ac.id/. Diakses pada 25 Desember 2018.

Isnawati \& Suhariadi. 2013. Hubungan antara Dukungan Sosial dengan Penyesuaian Diri Masa Persiapan Pensiun Karyawan PT. Pupuk Kaltim. Jurnal Psikologi Industri dan Organisasi. 2(1): 3.

Jati, Diyen Marror. 2017. Bentuk Dukungan Sosial Bagi Penderita
Gangguan

Jiwa

Berat

Skizofrenia (Studi pada Pasien Pasca Rehabilitasi di Rumah Sakit Jiwa Grhasia Yogyakarta).

Tersedia

http://etd.repository.ugm.ac.id.

Diaskes pada 25 Desember 2018.

Jones, P. 2016. Pengantar Teori-Teori Sosial dari Teori Fungsionalisme Hingga Post Modernisme. Jakarta: Pustaka Obor.

Keliat, B.A. 2011. Manajemen Kasus Gangguan Jiwa: CMHN (Intermediate Course). Jakarta: EGC.

Departemen Kesehatan RI. 2011. Deteksi Kesehatan Jiwa Dilakukan di Puskesmas. Tersedia di :http://www.depkes.go.id.

Diakses pada 3 Desember 2018. 2013. Hasil Riset Kesehatan Dasar 2013. Tersedia di: http://www.depkes.go.id.

Diakses pada 3 Desember 2018. 2016. HKJS 2016: Pertolongan Pertama Psikologis dan Kesehatan Jiwa Bagi Semua. Tersedia di: http://www.depkes.go.id.

Diakses pada 3 Desember 2018. 2017. Program Indonesia Sehat dengan Pendekatan Keluarga. Tersedia di: http://www.depkes.go.id.

Diakses pada 3 Desember 2018. 2018. Hasil Riset Kesehatan Dasar 2018. Tersedia di: http://www.depkes.go.id.

Diakses pada 3 Desember 2018.

Kuntjoro, Zainuddin.S. 2002. Dukungan Sosial pada Lansia. Tersedia di: http://www.e-psikologi.com.

Diakses pada 3 Desember 2018.

Maramis, W.F. 2009. Catatan IImu Kedokteran Jiwa Edisi 2. Surabaya: Airlangga University Press.

Moleong. J. Lexy. 2011. Metodologi Penelitian Kualitatif. Bandung: Rosdakarya

Nevid, S.Jeffrey. 2003. Psikologi Abnormal Jilid 1. Jakarta: Erlangga

Noor, Ronny. 2016. Stigmatisasi Penderita Gangguan Mental. 
Tersedia

di: https://www.kompasiana.com. Diakses pada 3 Desember 2018.

Notoatmodjo, S. 2005. Metodologi Penelitian Kesehatan. Jakarta: Rineka Cipta.

Nugroho, Ari. 2018. Jumlah Penderita Gangguan Jiwa di DIY Tertinggi di Indonesia. Tersedia di: https://jogja.tribunnews.com.

Diakses 3 Desember 2018.

Nurmanto, Fajar. 2015. Penderita Gangguan Jiwa Butuh Kepedulian Lebih Besar di Indonesia. Tersedia di: www.idntimes.com. Diakses pada 3 Desember 2018.

Pemerintah Republik Indonesia. 2014. Undang-Undang Nomor 18 Tahun 2014 Kesehatan Jiwa. Lembaran RI Tahun 2014 Nomor 185. Jakarta: Sekretariat Negara.

Poegoeh, Daisy Perwitasari. 2016. Peran Dukungan Sosial dan Regulasi Emosi Terhadap Resiliensi Keluarga Penderita Skizofrenia. Jurnal Psikologi. 1(1): 12-21.

Ritzer, George. 2012. Teori Sosiologi: dari Teori Sosiologi Klasik sampai Pengembangan Mutakhir Teori Sosial Postmodern. Jakarta: Kreasi Wacana.

Sarafino, E. P. 2008. Health psychology: Biopsychological Interactions (4rd ed). New York: John Wiley \& Sons, Inc.

Strauss, Anselm \& Juliet, Corbin. 2003. Dasar-dasar Penelitian Kualitatif. Yogyakarta: Pustaka Pelajar.

Sugiyono. 2016. Metode Penelitian Pendidikan. Bandung: Alfabeta

Supartika, Putu. 2018. Terdaftar Sebanyak 9.729 Warga Bali Derita Gangguan Jiwa. Tersedia di: https://video.tribunnews.com. Diakses pada 3 Desember 2018.

Surahmiyati, Sri. 2017. Dukungan Sosial untuk Orang dengan Gangguan Jiwa di Daerah Miskin: Studi Kasus di Gunungkidul. Berita Kedokteran Masyarakat. 33(8): 404-409.
Taylor .E, Shelley, dkk. 2009. Psikologi Sosial Edisi Kedua Belas. Jakarta: Kencana

Wardani. (2009). Riset Sumber Daya Manusia. Jakarta: PT. Gramedia Pustaka Utama.

White, K. 2012. Pengantar Sosiologi Kesehatan dan Penyakit. Jakarta: Raja Grafindo Persada.

Wiramihardja, Sutardjo. 2012. Pengantar Psikologi Klinis. Bandung: Refika Aditama

Yosep, Iyus. 2013. Keperawatan Jiwa. Bandung: Refika Aditama. 